\title{
Динаміка діастолічної функції лівого шлуночка серця спортсменів під час фізичних навантажень різної потужності
}

\author{
О. Б. Неханевич, О. Є. Дорофєєва, \\ В. Б. Бакурідзе-Маніна, А. О. Шелест
}

\begin{abstract}
ДЗ «Дніпропетровська медична академія МОЗ України», Дніпропетровськ, Україна
\end{abstract}

Резюме. Целью исследования было изучение динамики показателей диастолической функции сердца спортсменов во время физических нагрузок разной мощности по данным эхокардиографии. Были обследованы 68 спортсменов в возрасте от 12 до 27 лет, которые занимались плаваньем и волейболом. С помощью эходоплеркардиографического обследования были установлены особенности кардиогемодинамических сдвигов у спортсменов во время физических нагрузок различной мощности. Доказано, что физические нагрузки средней и субмаксимальной мощности приводят к пропорциональному увеличению показателей диастолической функции сердца. Ранними симптомами физического перенапряжения сердечно-сосудистой системы были признаки нарушения релаксации миокарда во время диастолы. Продолжение выполнения физической нагрузки приводило к снижению глобальной систолической функции левого желудочка сердца.

Ключевые слова: спортсмены, систолическая, диастолическая функция левого желудочка сердца, стресс-эхокардиография.

Summary. The objective of study was to examine the dynamics of diastole function indices of athletes under various physical loads according to echocardiography data. 68 athletes aged 12-27 practicing swimming and volleyball were examined. Echocardiography study has revealed peculiarities of cardiohemodynamic shifts in athletes under various physical loads. It has been proved that physical loads of average and submaximal intensity result in proportional increase of diastolic function indices. Disturbed myocardium relaxation during diastole has represented an early signs of physical overstrain of cardiovascular system. Physical load maintenance has resulted in the decrease of global systole function of the left ventricular

Key words: athletes, systolic, diastolic function of the left ventricular, stress-echocardiography.

Постановка проблеми. Визначення факторів, що впливають на рівень фрізичної працездатності людини, $є$ базовою науковою складовою сучасної спортивної медицини. Провідну роль у забезпеченні потреб організму у кисні та живильних речовинах, що зростають при фрізичних навантаженнях максимальної потужності, відіграє серцево-судинна система, зокрема резерв скорочувальної здатності серця. Під цим терміном розуміють ступінь можливого приросту скоротливої фрункції міокарда для забезпечення адекватного фрізичним навантаженням кровотоку [1]. На жаль, більшість дослідників та спортивних лікарів рідко враховують об'єктивні дані щодо змін у стані серця та кардіогемодинамічних зрушень під час навантажень різної потужності, а висновки базують на розрахункових методиках та припущеннях, що були запропоновані за формулою Ф. Бремзера та К. Е. Ранке ще наприкінці XIX ст.

Останнім часом в практику клінічної, зокрема спортивної, медицини увійшли нові методи оцінки гемодинамічних зрушень [5]. Найбільшого поширення серед них набула ехокардіографрія (ЕхоКГ), яка стала основним методом неінвазивної візуалізації у кардіології. Найважливішими та найбільш частими завданнями ЕхоКГ є кількісна та якісна оцінка стану порожнин серця, клапанів, міокарда та особливостей кардіогемодинаміки [16]. Однак стандартне дослідження стану серця та крупних судин за допомогою ЕхоКГ у більшості випадків проводиться у стані відносного спокою і не може дати відповідь щодо гострих зрушень у діяльності серцево-судинної системи під час виконання спортсменами інтенсивних фрізичних навантажень 
[5]. Для вирішення цих завдань у практику увійшла стрес-ехокардіографрія. Уперше ЕхоКГ для діагностики кардіогемодинамічних зрушень під час фрізичних навантажень було застосовано більше 20 років тому [20]. За цей час була розроблена доказова база, яка дає можливість об'єктивізувати дані щодо глобальної та регіональної систолічної функції [19], а також діастолічної функції лівого шлуночка серця [14]. Але досвід клініцистів розкриває переважно механізми адаптації серця при фрізичних навантаженнях у хворих на ішемічну хворобу серця, з патологією клапанів, гіпертрофрічною кардіоміопатією, перикардитом та хворих 3 серцевою недостатністю. Зміни ж гемодинаміки під час виконання фрізичних навантажень різної потужності висвітлено недостатньо [7, 10, 15]. Поодинокі праці в основному свідчать про те, що ступінь зсуву показників глобальної систолічної функції серця у спортсменів $\epsilon$ результатом багаторічного впливу фрізичних навантажень у стані спокою під час етапних медичних оглядів $[2,3]$.

Застосування стрес-ехокардіографрії у практиці спортивного лікаря має певні обмеження. По-перше, існуючі критерії гострих змін у серці під час фрізичних навантажень розроблялися для пацієнтів з ішемічною хворобою серця та клапанною патологією i, безумовно, не можуть у повному обсязі застосовуватися до спортсменів. Крім того, вони були визначені завдяки аналізу результатів, отриманих при субмаксимальних фрізичних навантаженнях, і в основному враховують показники регіональної скоротливості міокарда лівого шлуночка $[6,8,19]$. Тому дані щодо можливості використання стресс-ехокардіографії для діагностики гострих кардіогемодинамічних зрушень у спортсменів потребують уточнення та адаптації до умов спортивної діяльності.

Роботу виконано згідно з планом науково-дослідної теми «Медико-біологічне забезпечення фрізичної реабілітації, спортивних та оздоровчих тренувань» (номер держреєстрації 0113U007653) кафедри фрізичної реабілітації, спортивної медицини та валеології ДЗ «Дніпропетровська медична академія МОЗ України».

Мета дослідження - визначити динаміку показників діастолічної функції серця спортсменів під час фрізичних навантажень різної потужності за даними ехокардіографрії.

Матеріал та методи дослідження. Для вирішення поставлених завдань нами було обстежено 68 спортсменів віком від 12 до 27 років (середній вік $-17,8 \pm 4,5$ років), які займались спортивним плаванням та волейболом. На початку обстеження спортсмени мали спортивний стаж
$10,1 \pm 4,4$ роки. Середня тривалість тренувальних занять на тиждень становила 22,4 \pm 9,1 год. У дослідження включали спортсменів від I дорослого розряду до заслужених майстрів спорту, за спортивною спеціалізацією вони були представниками ігрових та циклічних видів спорту.

Комплексне обстеження проводили на загальнопідготовчому етапі базового мезоциклу річної підготовки спортсменів.

У стані фрізіологічного спокою проводили електрокардіографічне та ЕхоКГ обстеження спортсменів за стандартною методикою [1]. Після цього пацієнти виконували навантаження на вертикальному велоергометрі «Ketler XI» зі східчастим зростанням навантаження без періодів відпочинку. Початкове навантаження підбиралось з урахуванням маси тіла пацієнта й дорівнювало 1 Вт $\mathrm{Kг}^{-1}$. Навантаження поступово збільшували на $1 \mathrm{BT} \mathrm{kr}^{-1}$ кожні 2 хв. Частота педалювання становила 60 обертів за хвилину. Критеріями припинення навантаження були клінічні, фрункціональні чи електрокардіографрічні абсолютні показники згідно з рекомендаціями Американської асоціації серця [13]. Звичайно це відбувалось при досягненні максимальної ЧСС, що розраховувалась за фрормулою 220 - вік (у роках). Критерієм досягнення порогового рівня валідності тестування було обрано ЧСС, що розраховувалась за формулою ЧСС $=85 \%$ (220 - вік) [13]. Наприкінці кожного ступеня навантаження проводили еходоплеркардіографрічне дослідження: оцінювали динаміку фракції викиду та систолічного вкорочення лівого шлуночка у парастернальній позиції за довгою віссю серця, величину трансмітрального потоку та рух фріброзного кільця мітрального клапана у чотирьохкамерній апікальній позиції. У відновний період з третьої до п'ятої хвилини виконували електрокардіографрічне та ЕхоКГ обстеження за стандартними методиками.

Усім спортсменам проводили еходоплеркардіографрічне обстеження на апараті Philips HDI 5000 (США, 2004 р.) 3 використанням 2-4 МГц фразованого датчика у доплерівських режимах 2D, М-, кольоровому, імпульсно-хвильовому та постійно-хвильовому. Виміри розмірів та об'ємів камер серця проводили відповідно до рекомендацій Американського ехокардіографічного товариства $[12,16]$. Діастолічну фрункцію лівого шлуночка оцінювали за величинами трансмітрального потоку при імпульсно-хвильовій доплерограсрії й швидкості руху фріброзного кільця мітрального клапана в латеральній його частині при тканинній доплерографрії відповідно до рекомендацій Європейської ехокардіографрічної асоціації [17]. 


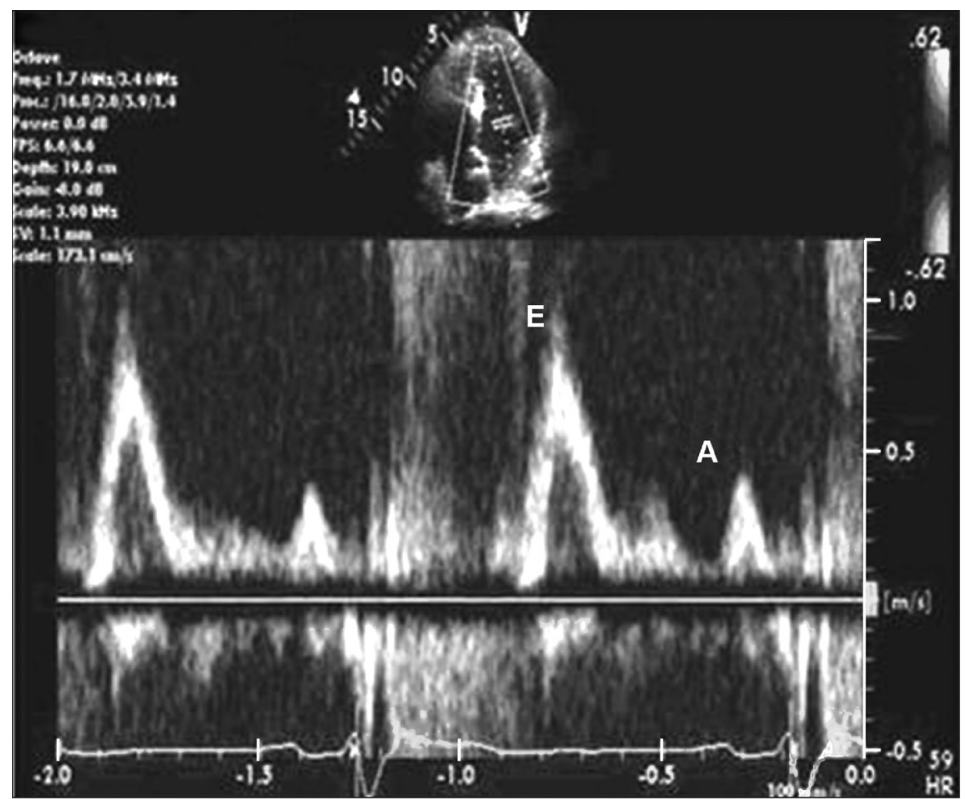

I

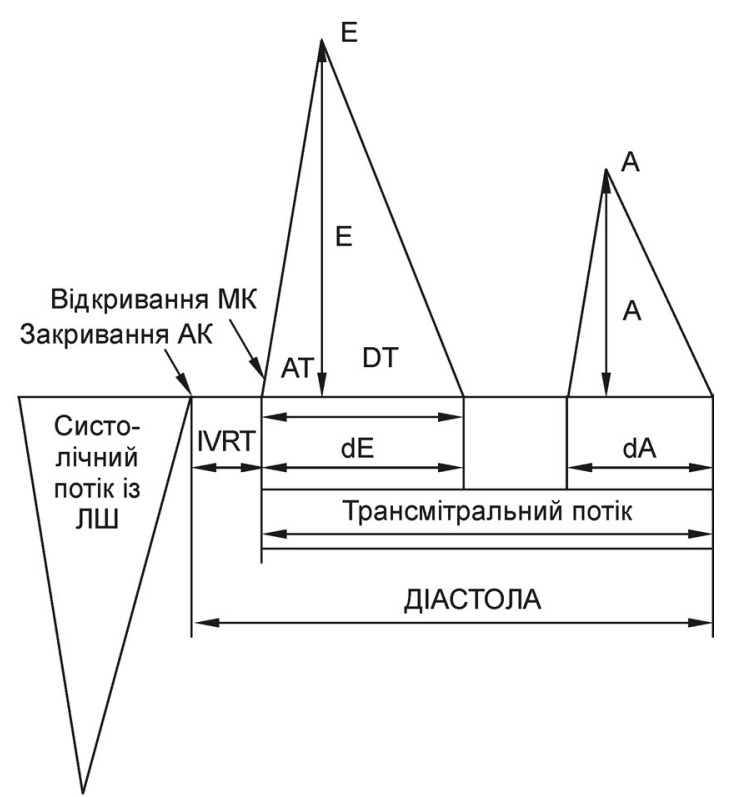

II

Рисунок 1 - Показники діастолічної функції лШ за трансмітральним потоком (I - зображення імпульсно-хвильової доплерехокардіографії; II - схема розрахунку показників [1]):

E - максимальна швидкість раннього діастолічного наповнення; А - максимальна швидкість наповнення у передсердну систолу; DT, AT - час уповільнення та прискорення ранньодіастолічного наповнення відповідно; dE, dA - тривалість ранньодіастолічного та пізньодіастолічного наповнення відповідно; IVRT - час ізоволюмічного розслаблення від моменту закриття аортального клапана до моменту відкриття мітрального клапана

Використовували показники максимальної швидкості раннього діастолічного $\left(\mathrm{E}, \mathrm{cm} \cdot \mathrm{c}^{-1}\right)$ та пізнього діастолічного (внаслідок скорочення передсердь - $\mathrm{A}, \mathrm{cm} \cdot \mathrm{c}^{-1}$ ) потоків на мітральному клапані, максимальної швидкості ранньодіастолічного $\left(\mathrm{e}^{\prime}, \mathrm{cm} \cdot \mathrm{c}^{-1}\right)$ та піздньодіастолічного $\left(\mathrm{a}^{\prime}\right.$, $\mathrm{cm} \cdot \mathrm{c}^{-1}$ ) руху фріброзного кільця мітрального клапана та їх співвідношення ( $\left.E / A, e^{\prime} / a^{\prime}, E / e^{\prime}\right)$.

Статистичну обробку отриманих результатів здійснювали за допомогою пакета ліцензійних прикладних програм STATISTICA $(6.1$, серійний номер AGAR909E415822FA) [4]. Аналізували вид розподілу показників за допомогою $\mathrm{W}$-критерію Шапіро-Уілка. Визначали достовірності відмінностей між показниками 3 урахуванням типу розподілу за допомогою t-критерію Стьюдента, U-критерію Манна-Уїтні та критерію $\chi^{2}$ Пірсона. Для визначення впливу досліджуваних фракторів використовували дисперсійний аналіз ANOVA/ MANOVA. За пороговий рівень статистичної значущості отриманих результатів було прийнято $\mathrm{p}<0,05$. Результати подано у вигляді $\mathrm{M} \pm \sigma$.

Роботу проведено 3 дотриманням нормативних документів комісії з медичної етики, розроблених з урахуванням положень Конвенції Ради

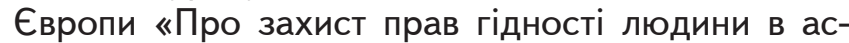
пекті біомедицини» (1997р.) та Гельсінкської декларації Всесвітньої медичної асоціації (2008р.).
Результати дослідження та їх обговорення. За спортивною кваліфікацією спортсмени були представлені на 14,7 \% (10 осіб) майстрами спорту міжнародного класу (МСМК), 38,2 \% (26 осіб) - майстрами спорту (МС), 27,9 \% (19 осіб) - кандидатами в майстри спорту (КМС), $19,1 \%$ (13 осіб) мали I розряд. Структуру за видами спорту становили на 85,3 \% представники циклічних видів (плавання) і на $14,7 \%$ - ігрових видів (волейбол).

Оцінка функкцій лівого шлуночка (ЛШ) серця $\epsilon$ найбільш частим завданням, що вирішується за допомогою ЕхоКГ. У клініці стало звичним розділяти ффункцію ЛШ на систолічну, або насосну (глобальну та регіонарну), й діастолічну, яка пов'язує показники діастолічного тиску та об'єму ЛШ, тобто характеризує особливості релаксації міокарда під час діастоли. Найбільш визнаним показником глобальної систолічної функції ЛШ $\epsilon$ фрракція викиду (ФВ) - характеризує відсоткове співвідношення кінцево-діастолічного та кінцевосистолічного розмірів ЛШ.

Останніми роками з'явились праці, що доводять можливість використання симптомів порушення релаксації міокарда, тобто діастолічної функції серця, як ранніх ознак перенапруження серцевої діяльності. При цьому у пацієнтів з такими ознаками ФВ може зберігатися на 
ТАБЛИЦЯ 1 - Показники діастолічної функції серця спортсменів за результатами доплерографії у стані спокою $(M \pm \sigma)$

\begin{tabular}{|c|c|c|c|c|c|}
\hline Показник & МСМК $(n=10)$ & $M C(n=26)$ & KMC $(n=19)$ & I розряд $(n=13)$ & Середнє $(n=68)$ \\
\hline $\mathrm{E}, \mathrm{CM} \cdot \mathrm{C}^{-1}$ & $87,6 \pm 27,8^{*}$ & $78,2 \pm 19,0$ & $69,0 \pm 8,3$ & $65,6 \pm 9,5$ & $74,6 \pm 18,1$ \\
\hline$A, C M \cdot c^{-1}$ & $40,4 \pm 19,8$ & $35,7 \pm 8,5$ & $34,1 \pm 8,4$ & $37, \pm 7,2$ & $36,2 \pm 10,6$ \\
\hline E\A, од. & $2,38 \pm 0,63^{*}$ & $2,18 \pm 0,43$ & $2,16 \pm 0,73$ & $1,83 \pm 0,50$ & $2,14 \pm 0,58$ \\
\hline Градієнт тиску, мм рт.ст. & $3,36 \pm 2,35^{*}$ & $2,42 \pm 0,94$ & $1,91 \pm 0,65$ & $2,16 \pm 0,94$ & $2,36 \pm 1,25$ \\
\hline $\mathrm{DT}, \mathrm{MC}$ & $133,8 \pm 44,7^{*}$ & $155,2 \pm 38,9$ & $177,7 \pm 49,8$ & $190,0 \pm 45,0$ & $163,4 \pm 46,7$ \\
\hline AT, MC & $110,0 \pm 26,7^{*}$ & $110,3 \pm 27,0$ & $123,2 \pm 42,6$ & $138,6 \pm 33,6$ & $118,6 \pm 33,9$ \\
\hline$e^{\prime}, c m \cdot c^{-1}$ & $14,9 \pm 1,4^{*}$ & $14,9 \pm 3,7$ & $11,0 \pm 2,9$ & $11,3 \pm 3,3$ & $13,1 \pm 3,7$ \\
\hline$a^{\prime}, \mathrm{cm} \cdot \mathrm{c}^{-1}$ & $6,76 \pm 1,64^{*}$ & $6,36 \pm 1,97$ & $4,77 \pm 1,25$ & $5,04 \pm 1,54$ & $5,72 \pm 1,82$ \\
\hline e'/a', од. & $2,38 \pm 0,95$ & $2,42 \pm 0,52$ & $2,45 \pm 0,91$ & $3,35 \pm 2,46$ & $2,60 \pm 1,29$ \\
\hline Е/e', од. & $5,86 \pm 1,45$ & $5,47 \pm 1,54$ & $6,66 \pm 1,73$ & $6,30 \pm 2,23$ & $6,02 \pm 1,77$ \\
\hline
\end{tabular}

${ }^{*} \mathrm{p}<0,05$

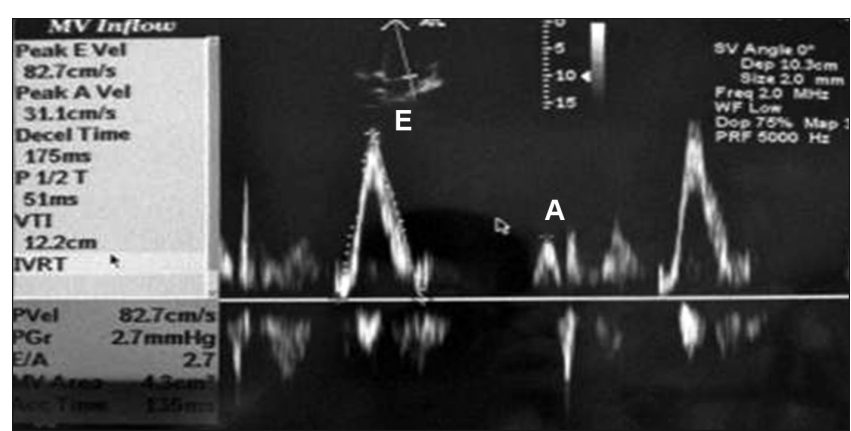

Рисунок 2 - Збільшення часу між ранньодіастолічною та пізньодіастолічною хвилею трансмітрального потоку за даними імпульсно-хвильового Доплера:

E - максимальна швидкість раннього діастолічного наповнення; А - максимальна швидкість наповнення у передсердну систолу

нормальному рівні $[15,18]$. Оскільки продуктивність роботи серця залежить не лише від його здатності викидати кров в аорту в систолу, але й від його можливості заповнюватися кров'ю в діастолу, критерієм порушеної діастолічної фрункції $\epsilon$ збільшення тиску наповнення ЛШ.

Оцінку діастолічної фрункції ЛШ проводили за допомогою імпульсно-хвильової доплерехокардіографії з верхівкового чотирикамерного зображення. Пробний об'єм величиною від 1 до 3 мм розміщують у вхідному тракті ЛШ у точці 3 найбільшою швидкістю. Зазвичай це вдається на рівні країв стулок мітрального клапана у діастолу (рис. 1).

Розрахунки показників вхідного потоку на мітральному клапані проводили упродовж трьох послідовних кардіоциклів та розраховували середній результат. Нормальна тривалість періоду IVRT становить 70-90 мс, при погіршенні розслаблення ЛШ ця величина зростає, час прискорення ранньодіастолічного потоку АТ в нормі становить $100 \pm 10$ мс, час уповільнення DT - $190 \pm 20$ мс, відношення Е/А у нормі коливається від 1,07 до 2,35 [1].

У нашому дослідженні показники трансмітрального потоку серця спортсменів не відрізнялись від середньопопуляційних. Але при детальному аналізі обраних показників залежно від кваліфрікації спортсменів було встановлено статистично значущі відмінності (табл. 1).

Внаслідок фрізіологічної брадикардії частота серцевих скорочень у середньому становила $51,1 \pm 4,8$ уд $\mathrm{xB}^{-1}$, у спортсменів відмічалось збільшення часу між ранньодіастолічною та пізньодіастолічною хвилею трансмітрального потоку (рис. 2).

Оцінку швидкості руху фріброзного кільця мітрального клапана проводили з використанням імпульсно-хвильової тканинної доплеркардіографії з верхівкового чотирикамерного зображення (рис. 3).

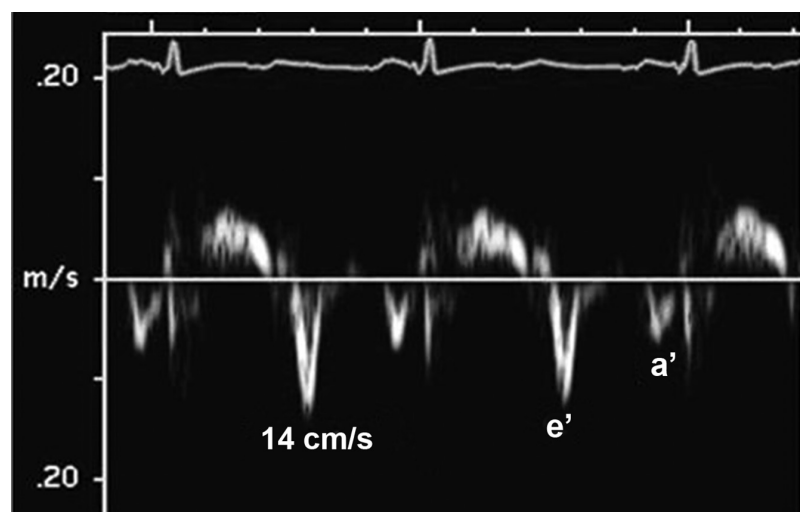

Рисунок 3 - Показники діастолічної функції ЛШ за швидкістю руху фріброзного кільця мітрального клапана. Зображення тканинної імпульсно-хвильової доплерехокардіографії:

е' - максимальна швидкість раннього діастолічного руху фріброзного кільця мітрального клапана; a' - максимальна швидкість руху фіброзного кільця мітрального клапана під час передсердної систоли 
ТАБЛИЦЯ 2 - Динаміка показників діастолічної функції серця спортсменів при фізичних навантаженнях різної потужності (M $\pm \sigma)$

\begin{tabular}{|c|c|c|c|c|c|}
\hline Показник & Стан спокою & $\begin{array}{c}50 \% \text { чСС } \\
\text { максимальної }\end{array}$ & $\begin{array}{c}75 \% \text { чсС } \\
\text { максимальної }\end{array}$ & $\begin{array}{c}90 \% \text { чСС } \\
\text { макасимальної }\end{array}$ & $\begin{array}{l}\text { Відновний } \\
\text { період }\end{array}$ \\
\hline $\mathrm{E}, \mathrm{CM} \cdot \mathrm{C}^{-1}$ & $74,6 \pm 18,1$ & $81,9 \pm 20,0$ & $102,2 \pm 32,9$ & $114,7 \pm 31,2^{*}$ & $94,89 \pm 22,6$ \\
\hline $\mathrm{A}, \mathrm{CM} \cdot \mathrm{C}^{-1}$ & $36,2 \pm 10,6$ & $35,3 \pm 8,3$ & $41,0 \pm 15,2$ & $45,2 \pm 14,2^{*}$ & $41,7 \pm 9,7$ \\
\hline E\A, од. & $2,14 \pm 0,58$ & $2,39 \pm 0,71$ & $2,68 \pm 0,96$ & $2,68 \pm 0,87^{*}$ & $2,36 \pm 0,55$ \\
\hline Градієнт тиску, мм рт.ст. & $2,36 \pm 1,25$ & $2,82 \pm 1,46$ & $4,23 \pm 2,76$ & $4,86 \pm 2,47^{*}$ & $3,81 \pm 1,89$ \\
\hline $\mathrm{DT}, \mathrm{MC}$ & $163,4 \pm 46,7$ & $184,1 \pm 48,2$ & $153,2 \pm 44,4$ & $132,5 \pm 69,0^{*}$ & $158,5 \pm 36,0$ \\
\hline AT, Mc & $118,6 \pm 33,9$ & $111,5 \pm 37,4$ & $116,8 \pm 27,2$ & $117,6 \pm 33,6$ & $104,4 \pm 20,2$ \\
\hline$e^{\prime}, c m \cdot c^{-1}$ & $13,1 \pm 3,7$ & $15,3 \pm 4,3$ & $16,6 \pm 5,7$ & $19,6 \pm 6,92^{*}$ & $19,3 \pm 4,2$ \\
\hline$a^{\prime}, c m \cdot c^{-1}$ & $5,72 \pm 1,82$ & $6,75 \pm 2,91$ & $6,71 \pm 2,28$ & $7,34 \pm 2,23^{*}$ & $8,03 \pm 1,86$ \\
\hline e'/a', од. & $2,60 \pm 1,29$ & $2,54 \pm 0,92$ & $2,59 \pm 0,88$ & $2,88 \pm 0,97$ & $2,47 \pm 0,57$ \\
\hline Е/e', од. & $6,02 \pm 1,77$ & $5,72 \pm 1,85$ & $6,73 \pm 2,83$ & $7,33 \pm 3,69^{*}$ & $5,07 \pm 1,37$ \\
\hline
\end{tabular}

${ }^{*} p<0,05$.

Результати вимірів повинні відображувати середні показники трьох послідовних кардіоциклів. Нормативні величини е' в середньому становлять від 10,4 до $14,9 \mathrm{~cm} \cdot \mathrm{c}^{-1}$, співвідношення $\mathrm{e}^{\prime} / \mathrm{a}^{\prime}-$ від 0,85 до $2,4 \mathrm{~cm} \cdot \mathrm{c}^{-1} .3$ віком еластичність міокарда знижується, що призводить до зменшення амплітуди е' та співвідношення $\mathrm{e}^{\prime} / \mathrm{a}^{\prime}$ і збільшення величини а' [17].

У нашому дослідженні співвідношення $\mathrm{e}^{\prime} / \mathrm{a}^{\prime}$ дещо перевищувало середньопопуляційний рівень, але різниця не була статистично значимою (див. табл. 1).

Стандартом оцінки діастолічної функції $€$ відношення $\mathrm{E} / \mathrm{e}^{\prime}$, тобто співвідношення максимальної швидкості раннього діастолічного наповнення ЛШ та максимальної тканинної швидкості раннього діастолічного зміщення кільця мітрального клапана. Величина $E / e^{\prime}$ менша за вісім виключає можливість підвищення тиску наповнення ЛШ. Збільшення ж E/e' більше 15 свідчить про його підвищення. 3 віком еластичність міокарда знижується, що призводить до збільшення співвідношення $\mathrm{E} / \mathrm{e}^{\prime}$ [17].

Співвідношення $\mathrm{E} / \mathrm{e}^{\prime}$ у спортсменів не відрізняється від загальнопопуляційного рівня (див. табл. 1).

Дослідження ступеня релаксації міокарда в процесі виконання фрізичних навантажень вказує, що при навантаженнях субмаксимальної потужності швидкості E та е' зростають пропорційно, що підтверджує дані міжнародних досліджень [14]. Таким чином, співвідношення $\mathrm{E} / \mathrm{e}^{\prime}$ залишається незмінним або незначно знижується (табл. 2, рис. 4).
При надмірних порогових навантаженнях та у осіб з порушеною релаксацією міокарда зі зростанням навантаження збільшення е' менше, ніж $\mathrm{E}$, що призводить до підвищення співвідношення $\mathrm{E} / \mathrm{e}^{\prime}$ (табл. 2.). Ці дані свідчать про можливість використання стрес-ехокардіографрії для діагностики резерву діастолічної функції міокарда.

Додатковим показником можна вважати тривалість інтервалу DT, яка в нормі при субмаксимальних навантаженнях у осіб з нормальною релаксацією міокарда зменшувалась незначно, а при надмірних порогових навантаженнях скорочувалась більше ніж на 50 мс. Ці дані співпадають із результатами дослідження, в якому безпосередньо вимірювали тиск у ЛШ за допомогою катетеризації камер серця [9].

Особливий інтерес викликають дані щодо динаміки показників діастолічної фрункції у відновний період після припинення виконання навантаження. Дані літератури вказують, що у пацієнтів 3 порушенням розслаблення міокарда внаслідок ішемічної хвороби серця елевація зубця $\mathrm{E}$ продовжується ще 5-10 хв, натомість амплітуда е' зменшувалась відразу після припинення навантаження, що призводило до збільшення співвідношення $\mathrm{E} / \mathrm{e}^{\prime}$. У пацієнтів 3 нормальною діастолічною функцією зменшення $\mathrm{E}$ та е' відбувалось пропорційно [11]. У нашому дослідженні після припинення виконання навантаження величина $\mathrm{E}$ зменшувалась більш швидко, ніж е', тому відношення $\mathrm{E} / \mathrm{e}^{\prime}$ знизилась нижче, ніж у стані спокою до навантаження (див. табл. 2).

Рисунок 4 - Динаміка показників трансмітрального кровотоку при фрізичних навантаженнях різної потужності: I - вхідний потік на мітральному клапані; II - рух фіброзного кільця мітрального клапана; А - у стані спокою; Б - при навантаженні на рівні 50 \% максимального; В - при навантаженні на рівні 75 \% максимального; Г - відновний період на третій хвилині після фрізичного навантаження 

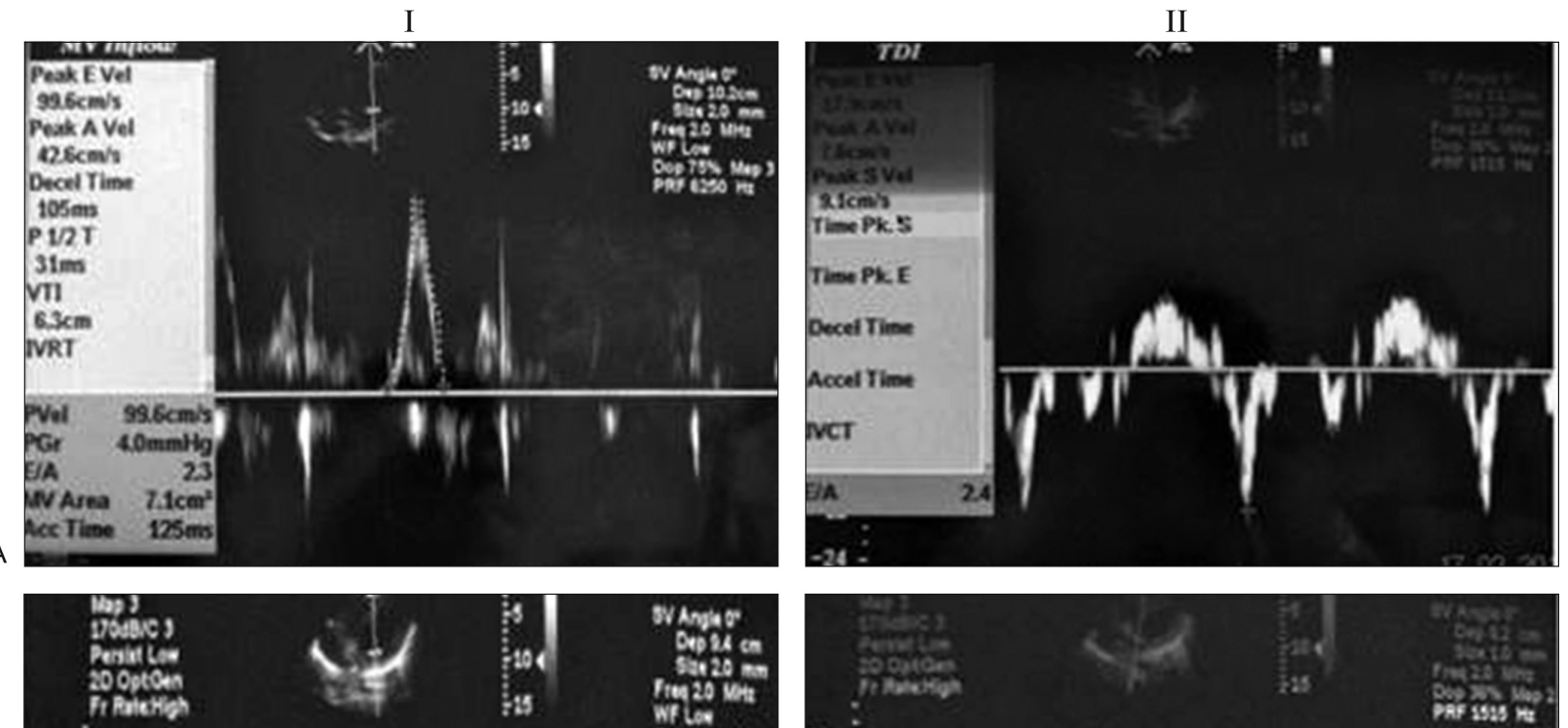

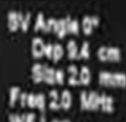

200 -

00020 vap

160 -

Б
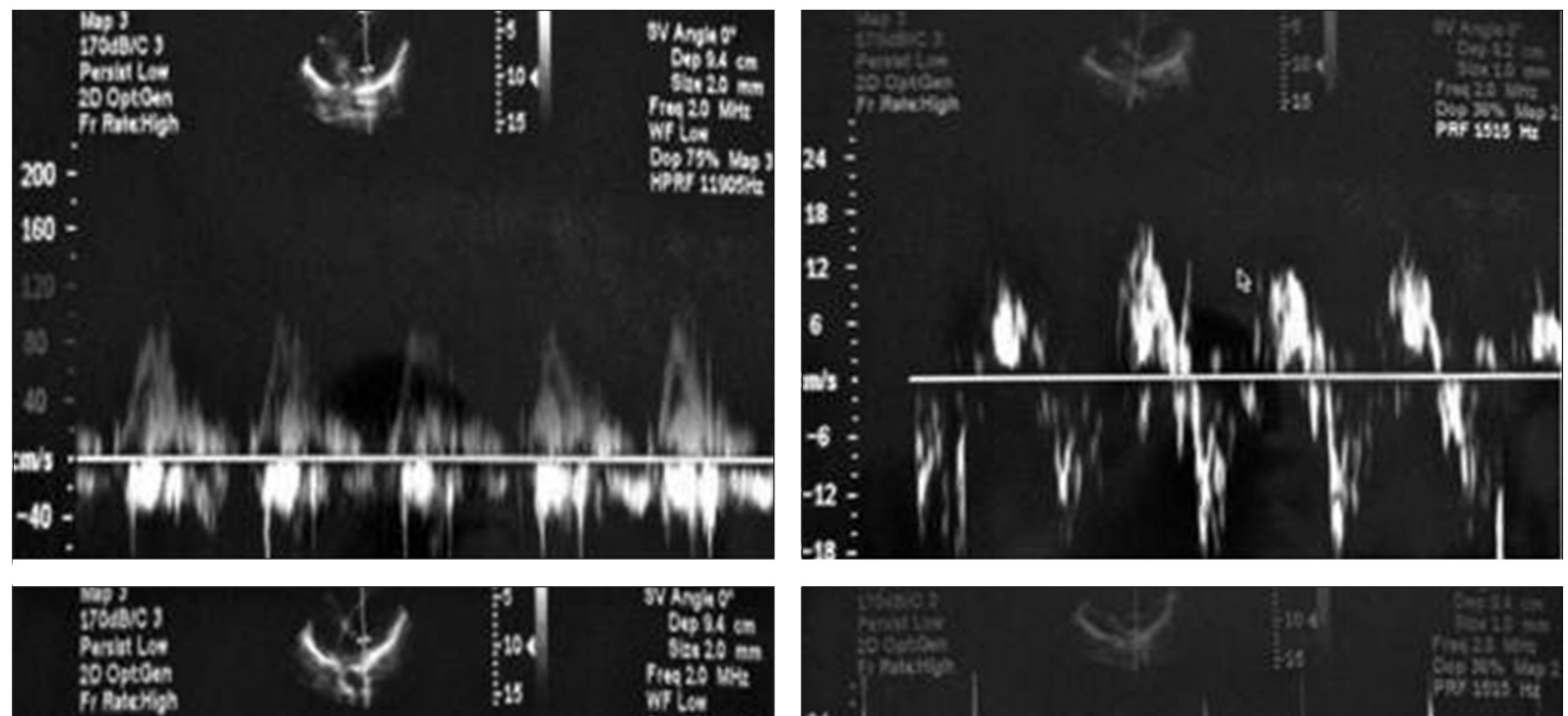

Sortion $8 a 20 \mathrm{mn}$ fou 20 use Finterion

35

Nitco

200 .

optis me

W

WPW HEG

B
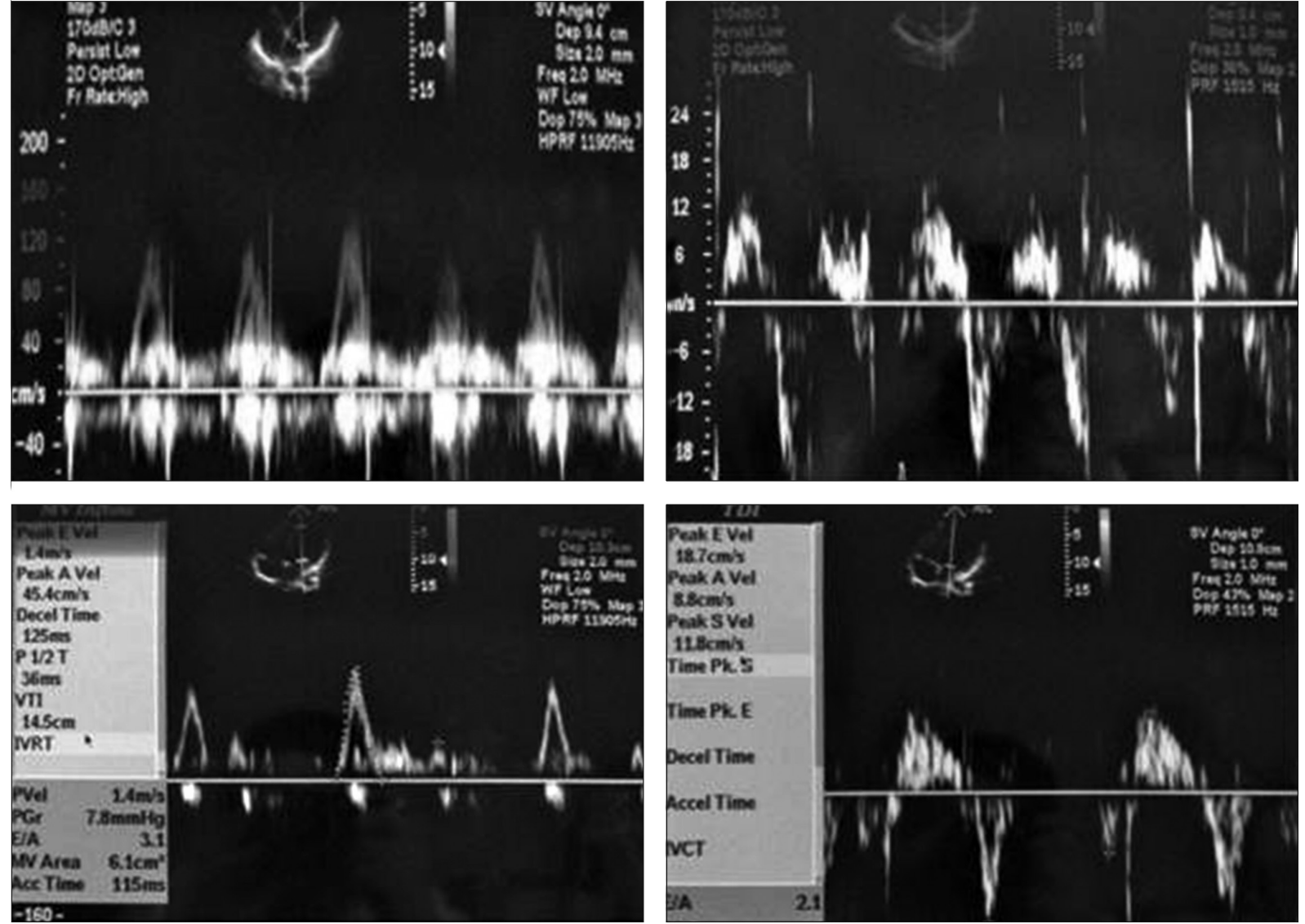


\section{Висновки}

В роботі доведено, що фрізичні навантаження середньої та субмаксимальної потужності призводять до пропорційного зростання показників діастолічної функції серця. Ранніми симптомами фрізичного перенапруження серцево-судинної системи були ознаки порушення релаксації міокарда під час діастоли, що проявлялось у збільшенні співвідношення між максимальною швидкістю раннього діастолічного наповнення лівого шлуночка та максимальною тканинною швидкістю раннього діастолічного зміщення кільця мітрального клапана. Це можна використовувати як ранню ознаку фрізичного перенапруження

\section{Література}

1. Коваленко В. М. Настанова з кардіології / В. М. Коваленко, М. І. Лутай, В. В. Братусь [та ін.]; за ред. В. М. Коваленка. - К. : МOPIOH, 2009. - 1368 с.

2. КриВолап Н. В. Диспластична кардіопатія у футболістів: особливості прояву залежно від віку, статі та спортивного стажу / Н. В. Криволап // Спорт. медицина. 2014. - № 1. - С. 95-101.

3. Михалюк Е. Л. Диагностическая чувствительность нагрузочного тестирования, эхокардиография и динамика тропонинов I у спортсменов высокого класса в верификации метаболической кардиомиопатии физического перенапряжения / Е. Л. Михалюк, В. В. Сыволап // Патологія. 2007. - № 1. - С. 62-66.

4. Халаффян A. A. STATISTICA 6. Статистический анализ данных / А. А. Халафян. - М.: ООО «Бином-Пресс», 2007. -512 c.

5. Шляхто E. B. Соременные методы оценки прогноза при сердечной недостаточности / Е.В.Шляхто, М.Ю.Ситникова / / Журн. сердеч. недостаточность. - 2010. - Т. 10, № 6. - С. 322-335.

6. Шуленин К. С. Диагностика сердечной недостаточности с помощью стресс-эхокардиографии / К. С. Шуленин, Г. Г. Хубулава, А. Л. Бобров [и др.] // Вестн. Рос. военно-мед. акад. - 2010. - № 3 (31). - С. 21-25.

7. Юмалин C. X. Состояние миокарда у юных спортсменов по данным эхокардиографии / С. Х. Юмалин, Л. В. Яковлева, Р. М. Кофмман // Соврем. пробл. науки и образования. - 2013. - № 3. - С. 448.

8. Bombardini T. Diastolic time - frequency relation in the stress echo lab: filling timing and flow at different heart rates / T. Bombardini, V. Gemignani, E. Bianchini [et al.] // Cardiovascular Ultrasound. - 2008. - Vol. 6. - P. 1-20.

9. Burgess M. I. Diastolic stress echocardiography: hemodynamic validation and clinical significance of estimation of ventricular filling pressure with exercise / [M. I. Burgess, C. Jenkins, J. E. Sharman, T. H. Marwick] // J. Amer. Coll Cardiol. - 2006. - Vol. 47. - P. 1891-1900.

10. Cotrin $C$. Clinical applications of exercise stress echocardiography in the treadmill with upright evaluation during and after exercise / C. Cotrim, I. Joro, P. Fazendas [et al.] / / Cardiovascular Ultrasound. - 2013. - P. 11-26.

11. Duncan A. M. Effect of dobutamine stress on left ventricular filling in ischemic dilated cardiomyopathy: pathophysiology and prognostic implications / A. M. Duncan, E. Lim, D. G. Gibson, M. Y. Henein / / J. Amer. Coll Cardiol. 2005. - Vol. 46. - P. 488-496. серцево-судинної системи і для діагностики резерву діастолічної фрункції міокарда.

Різниця за рівнем релаксації міокарда під час діастоли серед спортсменів різної кваліфрікації вказує на можливість використання показників діастолічної фрункції серця як критеріїв тренованості та для спортивного відбору у видах спорту, що розвивають переважно якість витривалості.

Перспективи подальших досліджень полягають у співставленні ранніх ознак перенапруження діастолічної фрункції лівого шлуночка серця з показниками загальної та спеціальної фрізичної працездатності у спортсменів різних видів спорту.

\section{References}

1. Kovalenko V. M. Instruction of cardiology / V. M. Kovalenko, M. I. Luhai, V. V. Bratus [et al.]; Ed. by V. M. Kovalenko. - Kyiv : MORION, 2009. - 1368 p.

2. Kryvolap N. V. Dysplastic cardiopathy in footballers: peculiarities of manifestation depending on age, sex and experience / N. V. Kryvolap // Sportyvna medytsyna. - 2014. N 1. - P. 95-101.

3. Mikhalyuk E. L. Diagnostic sensitivity of load testing, echocardiography and dynamics of troponins I in highly skilled athletes in verification of metabolic cardiomyopathy of physical overload / E. L. Mikhalyuk, V. V. Syvolap // Patolohiia. 2007. - N 1. - P. 62-66.

4. Khalafyan A. A. STATISTICA 6. Data statistical analysis / A. A. Khalafyan. - Moscow: 000 «Binom-Press», 2007. -512 p.

5. Shlyakhto E. V. Modern methods of prognosis assessment during heart failure / E. V. Shlyakhto, M. Y. Sitnikova // Zhurnal serdechnaya nedostatochnost. - 2010. - Vol. 10, N 6. - P. 322-335.

6. Shulenin K. C. Heart failure diagnostics by stress-echocardiography / K. C. Shulenin, G. G. Khubulava, A. L. Bobrov [et al.] // Vestn. Ros. voyenno-med. akad. - 2010. - N 3 (31). - P. 21-25.

7. Yumalin S. H. State of myocardium in young athletes according to echocardiography data / S. H. Yumalin, L. V. Yakovleva, R. M. Kofman // Sovrem. Problem nauki I obrazovaniya. - 2013. - N 3. - P. 448.

8. Bombardini $T$. Diastolic time - frequency relation in the stress echo lab: filling timing and flow at different heart rates / T. Bombardini, V. Gemignani, E. Bianchini [et al.] // Cardiovascular Ultrasound. - 2008. - Vol. 6. - P. 1-20.

9. Burgess M. I. Diastolic stress echocardiography: hemodynamic validation and clinical significance of estimation of ventricular filling pressure with exercise / [M. I. Burgess, C. Jenkins, J. E. Sharman, T. H. Marwick] // J. Amer. Coll Cardiol. - 2006. - Vol. 47. - P. 18911900.

10. Cotrin C. Clinical applications of exercise stress echocardiography in the treadmill with upright evaluation during and after exercise / C. Cotrim, I. Joro, P. Fazendas [et al.] // Cardiovascular Ultrasound. - 2013. - P. 11-26.

11. Duncan A. M. Effect of dobutamine stress on left ventricular filling in ischemic dilated cardiomyopathy: pathophysiology and prognostic implications / A. M. Duncan, E. Lim, D. G. Gibson, Henein M. Y. / / J. Amer. Coll Cardiol. 2005. - Vol. 46. - P. 488-496. 
12. Evangelista A. European Association of Echocardiography recommendations for standardization of performance, digital storage and reporting of echocardiographic studies / F. Evangelista, F. Flachskampf, P. Lancellotti [et al.] // Eur. J. Echocardiogr. - 2008. - Vol. 9. - P. 438-448.

13. Fletcher G. F. Exercise Standards for Testing and Training: A Scientific Statement From the American Heart Association / G. F. Fletcher, P. A. Ades, P. Kligfield [et al.] / Circulation. - 2013. - Vol. 128. - P. 873-934.

14. Ha J. W. Diastolic Stress Echocardiography: A Novel Noninvasive Diagnostic Test for Diastolic Dysfunction Using Supine Bicycle Exercise Doppler Echocardiography / J. W. Ha, J. K. Oh, P. A. Pelikka [et al.] // J. the Amer. Soc. Echocardiography. - 2005. - Vol. 18 (1). - P. 63-68.

15. Knebel $F$. Exercise-induced changes of left ventricular diastolic function in postmenopausal amateur marathon runners: assessment by echocardiography and cardiac biomarkers / F. Knebel, S. Spethmann, S. Schattke [et al.] // Eur. Preventive Cardiology. - 2014. - Vol. 21 (6). - P. 782-790.

16. Lang R. M. Recommendations for chamber quantification / R. M. Lang, M. Bierig, R. B. Devereux [et al.] // Eur. J Echocardiogr. - 2006. - Vol. 7. - P. 79-108.

17. Nagueh S. F. Recommendations for the evaluation of left ventricular diastolic function by echocardiography / S. F. Nagueh, C. P. Appleton, T. C. Gillebert [et al.] // Eur. J. Echocardiogr. - 2009. - Vol. 10. - P. 165-93.

18. Paulus W. J. How to diagnose diastolic heart failure: a consensus statement on the diagnosis of heart failure with normal left ventricular ejection fraction by the Heart Failure and Echocardiography / W. J. Paulus, C. Tschope, J. E. Sanderson [et al.] / / Eur. Heart J. - 2007. - Vol. 28. - P. 2539-2550.

19. Sicari R. European Association of Echocardiography. Stress echocardiography expert consensus statement: European Association of Echocardiography (EAE) (a registered branch of the ESC) / R. Sicari, P. Nihoyannopoulos, A. Evangelista [et al.] // Eur. J. Echocardiogr. - 2008. - Vol. 9. P. 415-437.

20. Wann L. S. Exercise cross-sectional echocardiography in ischemic heart disease / L. S. Wann, J. V. Faris, R. H. Childress [et al.] / / Circulation. - 1979. - Vol. 60. - P. 13001308.
12. Evangelista A. European Association of Echocardiography recommendations for standardization of performance, digital storage and reporting of echocardiographic studies / F. Evangelista, F. Flachskampf, P. Lancellotti [et al.] // Eur. J. Echocardiogr. - 2008. - Vol. 9. - P. 438-448.

13. Fletcher G. F. Exercise Standards for Testing and Training: A Scientific Statement From the American Heart Association / G. F. Fletcher, P. A. Ades, P. Kligfield [et al.] / Circulation. - 2013. - Vol. 128. - P. 873-934.

14. Ha J. W. Diastolic Stress Echocardiography: A Novel Noninvasive Diagnostic Test for Diastolic Dysfunction Using Supine Bicycle Exercise Doppler Echocardiography / J. W. Ha, J. K. Oh, P. A. Pelikka [et al.] // J. the Amer. Soc. Echocardiography. - 2005. - Vol. 18 (1). - P. 63-68.

15. Knebe/ $F$. Exercise-induced changes of left ventricular diastolic function in postmenopausal amateur marathon runners: assessment by echocardiography and cardiac biomarkers / F. Knebel, S. Spethmann, S. Schattke [et al.] // Eur. Preventive Cardiology. - 2014. - Vol. 21 (6). - P. 782-790.

16. Lang R. M. Recommendations for chamber quantification / R. M. Lang, M. Bierig, R. B. Devereux [et al.] // Eur. J. Echocardiogr. - 2006. - Vol. 7. - P. 79-108.

17. Nagueh S. F. Recommendations for the evaluation of left ventricular diastolic function by echocardiography / S. F. Nagueh, C. P. Appleton, T. C. Gillebert [et al.] // Eur. J. Echocardiogr. - 2009. - Vol. 10. - P. 165-93.

18. Paulus $W$. J. How to diagnose diastolic heart failure: a consensus statement on the diagnosis of heart failure with normal left ventricular ejection fraction by the Heart Failure and Echocardiography / W. J. Paulus, C. Tschope, J. E. Sanderson [et al.] / / Eur. Heart J. - 2007. - Vol. 28. - P. 2539-2550.

19. Sicari R. European Association of Echocardiography. Stress echocardiography expert consensus statement: European Association of Echocardiography (EAE) (a registered branch of the ESC) / R. Sicari, P. Nihoyannopoulos, A. Evangelista [et al.] // Eur. J. Echocardiogr. - 2008. - Vol. 9. P. 415-437.

20. Wann L. S. Exercise cross-sectional echocardiography in ischemic heart disease / L. S. Wann, J. V. Faris, R. H. Childress [et al.] // Circulation. - 1979. - Vol. 60. - P. 13001308. 